口繁 殖 学 $\square$ 研究短報

\title{
雌アジアゾウにおける発情周期中の 腟前庭粘膜面の肉眼的変化
}

土井 守 ${ }^{1)}$, 山田朋美 ${ }^{1)}$, 寺園美奈子 ${ }^{1)}$, 和田晴太郎 ${ }^{21}$, 秋久成人 ${ }^{21}$, 坂本英房 ${ }^{2)}$, 濱崎 勤 ${ }^{21}$ 柳本 博2), 中野和彦 ${ }^{2)}$, 松岡賢司 ${ }^{2)}$, 伊藤 淳 ${ }^{2)}$, 岩橋宣明 ${ }^{2)}$, 水野章裕 ${ }^{2}$, 楠 比呂志 ${ }^{3)}$

1)岐皁大学農学部生物資源生産学科 ₹ 501-1193 岐阜県岐阜市柳戸 1-1

2) 京都市動物園 ₹ 606-8333 京都府京都市左京区岡崎法勝寺町

3) 神戸大学農学部附属農場 $=675-2103$ 兵庫県加西市鶕野町 1348

(2001.8.23 受付, 2001.10.24 受理)

\section{Macroscopic Changes in the Mucous Membrane of Vaginal Vestibule during the Estrous Cycle of Female Asian Elephant}

Osamu DOI ${ }^{1)}$, Tomomi YAMADA ${ }^{1)}$, Minako TERAZONO ${ }^{1)}$, Seitaro WADA ${ }^{2)}$, Narito AKIHISA ${ }^{21}$, Hidefusa SAKAMOTO ${ }^{2)}$, Tsutomu HAMAZAKI ${ }^{2)}$, Hiroshi YANAGIMOTO'), Kazuhiko NAKANO ${ }^{2)}$, Kenji MATSUOKA ${ }^{2)}$, Atsushi ITO $^{2)}$, Nobuaki IWAHASHI'), Akihiro MIZUNO ${ }^{2)}$, Hiroshi KUSUNOKI ${ }^{3)}$

1) Division of Biological Resources and Production, Faculty of Agriculture, Gifu University, Gifu 501-1193, Japan 2) Kyoto Municipal Zoo, Sakyo-ku, Kyoto 606-8333, Japan

3) Experimental Farm, Faculty of Agriculture, Kobe University, Hyogo 675-2103, Japan

\begin{abstract}
This study attempted to clarify the relationship between macroscopic observation of the vaginal vestibule and changes in the blood progesterone level during the estrous cycle of female Asian ele. phants. Clear congestion was observed extensively on the mucous membrane of the vaginal vestibule when progesterone was at its lowest level. As the level increased, sporadic erythema and swelling as well as papules were observed near the congested area close to the vulva. However, the trend that congestion on the mucous membrane was alleviated as the blood progesterone level dropped was also noted.
\end{abstract}

Key Words: Asian elephant, vaginal vestibule, progesterone

Jpn.J.Zoo Wildl.Med. 6(2) : 55-59, 2001

飼育下でゾウの発情期を判定する方法には，血中のホル モン濃度の測定 [1-3] や行動の観察 [4] などがある。ゾ ウの発情周期は, 血液中の性ステロイドホルモン濃度の測 定結果から，15〜17 週間であることが既に証明されている [1-3]。また, 䧳雄同居させて飼育している施設では, 尿テ ストなどの種々の行動の変化を観察するなど, 雌ゾウの発 情時期を確実にとらえる方法が検討されている。しかし,成 熟した雄ソウウには，1 年のうち数ヶ月間ムストと呼ばれる 粗暴になる時期があり [4], 飼育する上で大きな問題点を
抱えているため, 雌雄ともに飼育している施設は少ない。飼 育下でゾウを繁殖させるためには，雌雄ともに飼育してい る施設において,まず自然に繁殖を試みる必要があるが, 必 ずしも相互の相性や年齢が合わないことなどから，日本に おいては出産例が極めて少ない。そこで，数少ない飼育下 の雄ゾウから精液を採取して保存を検討する一方で, 雌ゾ ウの発情周期を容易に判定できる方法の確立が望まれてい る。そこで, 我々は血中のプロジェステロン濃度の変動を もとに腟前庭スメアにおける脱落細胞像の観察を行った結 
果，黄体期以外の時期での大型角化細胞の増加が明らかと なり, 胵前庭スメアの細胞像の変化から発情周期を決定で きる可能性を示唆した $[5]$ 。さらに本研究では，よく調教 が行き届いた䧳アジアゾウを用いて, 各個体の発情周期中 における腟前庭粘膜面の充血などの肉眼的変化を観察する ことにより，血中のプロジェステロン濃度変化との関係を 明らかにしょうとした。

この実験では, 京都市動物園で飼育されている雌 2 頭 (実 験開始時推定年齢 13 歳と 23 歳)を使用した。採血は, ゾウ が立位の状態で後肢内側の伏在静脈から 1 週間間隔で合計 65 週間行った。また，採血と同時に，ゾウの後肢間に開口 する外陰部を手によって広げ，腟前庭部における粘膜面の 状態を写真撮影した。また, 血液は室温で約 20 分間静置し た後, $3000 \mathrm{rpm} て ゙ 15$ 分間遠心分離することにより血清を 採取し,測定に使用するまでー $80^{\circ} \mathrm{C}$ 下で涷結して保存した。 凍結保存された血清は，融解後直ちに $0.1 \sim 0.2 \mathrm{ml}$ を小試 験管に分注した。ステロイドホルモンの抽出のために,各々 の試験管内に 3〜4 倍量のエチルエーテルを入れ混合した 後静置し, $-60^{\circ} \mathrm{C}$ 下で血清層を凍結し,傾斜法によって上層 のエーテル層を別の試験管に移した。この操作を 4 回繰り 返した後, $40^{\circ} \mathrm{C}$ 温湯中でエーテルを揮発させた。その後, 測定用試料を減圧下で 10 分間吸引した後，試験管内に $1 \%$ 牛血清アルブミンーリン酸緩衝液 $0.2 \mathrm{ml}$ を入れて混和し た。これを測定用試料とした。ラジオイムノアッセイ法は， 中村ら [6] の方法に従って行われた。また，使用したプロ ジェステロン抗体の各種のステロイドホルモンに対する交 叉率は，Doi ら [7] の報告で示されている。な扔，放射能 の測定には，液体シンチレーションカウンター(Tri -Carb 2500 TR, Packard USA)を用いた。

今回調查したアジアゾウ 2 頭における血清中プロジェス テロン濃度の変動と，採血時に同時に撮影した臸前庭粘膜 面の写真の一例を，図 1,2 および 3 に示した。アジアゾウ の血中プロジェステロン濃度は, $0.10 \pm 0 〜 2.06 \pm 0.31 \mathrm{ng} /$ $\mathrm{ml}$ の範囲内を 14〜17 週間で顕著に変動していた。血中プ ロジェステロン濃度が最も低い時期の胵前庭粘膜面では, 明らかに広範囲の充血が認められ，わずかな出血を伴う場 合も認められた。その後, 血中プロジェステロン濃度の上 昇開始時期から上昇後ピークに達するまで，プロジェステ ロン濃度が低い時期に認められた充血部より外陰部側に多 くの紅斑や腫脹が散在し，なかには丘疹も認められた。ま
た，血中プロジェステロン濃度が減少するにつれて，粘膜 面に認められた充血部位が狭くなる例ならびに充血や紅斑 部位の色調が緩和する例が観察された。しかし，実験に供 した両個体間または同一個体においても観察した時期など によって，充血部の広がりゃ腫脹の隆起傾向などが若干異 なることも観察された。これらのことからアジアゾウ 2 頭 計 6 回の発情周期について検討した結果, 両者の雌ゾウと もに血中プロジェステロン濃度の変動に従って, 胵前庭粘 膜面における様相が顕著に変化することが明らかとなっ た。

ゾウの発情周期の長さは, 血中性ステロイド濃度の測定 結果から 15～17 週間であると報告されている $[1,2]$ 。とく にアジアゾウの発情周期について詳細に調べた報告では, 血中プロジェステロン濃度の変化から $16.8 \pm 0.6$ 週間であ ると報告されている $[3]$ 。本実験結果もほほ同様に，血中 プロジェステロン濃度が 14〜17 週間で顕著に変動してい

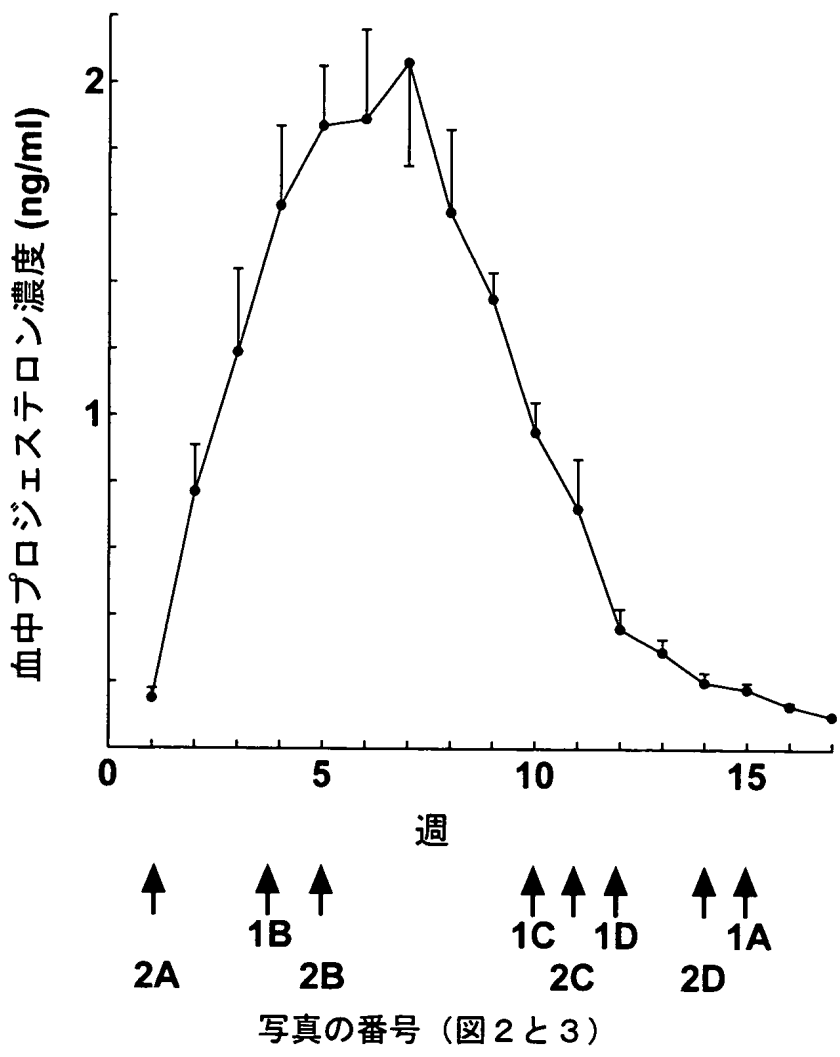

図 1 踓アジアゾウの発情周期中における血中プロジェ ステロン濃度の変化 $(n=4 \sim 6)$

図の下の番号と矢印は, 図 2 と 3 で示した写真の番号 と撮影した時期を示す。 


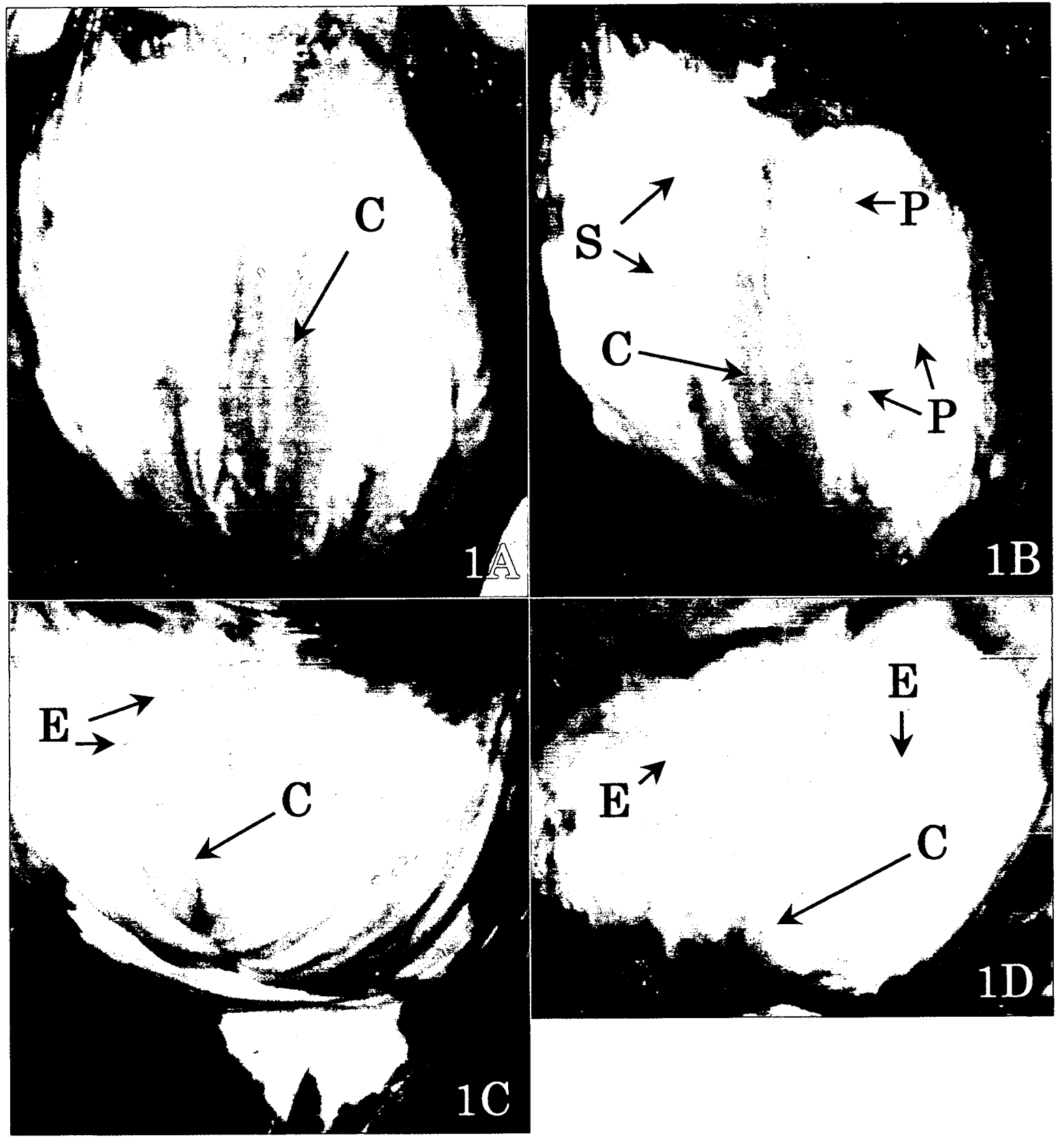

図 2 雌アジアゾウの発情周期中における腟前庭粘膜面の肉眼的変化(個体 A)

$\mathrm{C}$ : 充血, $\mathrm{S}$ : 腫脹, $\mathrm{E}:$ 紅斑, $\mathrm{P}$ : 丘疹

た。血中のホルモン濃度を測定することにより発情時期を 決定することができるが，それには特殊な機器を必要とす る上，時間を要する。そこで飼育施設でのゾウの行動調査 を行うことにより，これまでにゾウの発情時期を見出す方 法が検討されてきた。雄ゾウが崔の発情を調べる代表的な 行動として，尿テストが古くから知られている [4]。尿テ ストとは，雄が唯の外陰部に奥先を挿入して直ちに自分の ロに入れる行動であり，雄はその行動により雌のある種の
フェロモン様物質を感知して発情を認知するものと考えら れている。この尿テストの陽性率が高まる時期と排卵時期 がほぼ一致することが, 血中のプロジェステロン濃度の変 化から明らかにされている [1]。しかし，日本ではほとん どの施設で雌のみを飼育していることから，雄の精液採取 や保存の研究を一方で行うとともに, 雌のみ飼育している 施設においても的確に発情を判定できる方法の検索が必要 である。そこで, 我々は雌アジアゾウの腟前庭スメアを血 


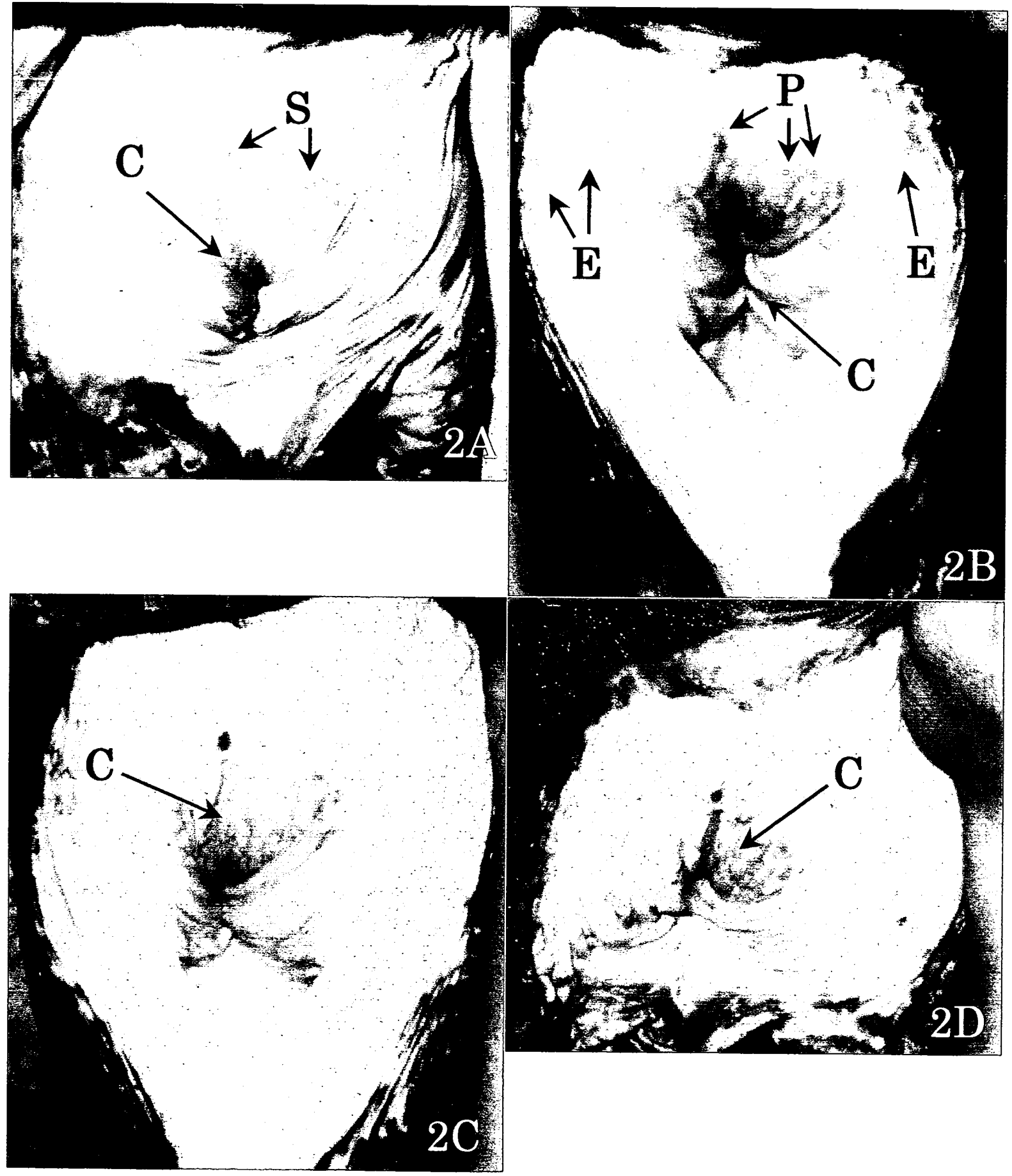

図 3 雌アジアゾウの発情周期中における腟前庭粘膜面の肉眼的変化 (個体 B)

$\mathrm{C}:$ 充血, $\mathrm{S}$ : 腫脹, $\mathrm{E}:$ 紅斑, $\mathrm{P}$ : 丘疹

中のプロジェステロン濃度の変化とともに長期間観察した 結果, 発情期を中心に大型の角化細胞の出現率が高まるこ 'とを報告した $[5]$ 。さらに本研究の結果から, 雌アジアゾ ウの場合も血中プロジェステロン濃度の低い時期から上昇 前の時期にかけて発情と排卵が起こっているものと考えら
れるため, 腟前庭粘膜面において充血が認められる時期が 発情期と考えられた。また，その外陰部側に腫脹や丘疹が 認められはじめる時期が発情後期と推察した。このような 観察を行うためにはゾウの後肢間に人間が入ることになる ため，実施するにあたってはゾウがよく調教されているこ 
とが必須となる。しかし，直接飼育法で飼育され調教がよ く施されている施設であれば，先に報告した腟前庭スメア の細胞像の観察 [5] とともに外陰部を反転して粘膜面を肉 眼的に観察することによって，アジアゾウ個体の発情期を 容易に確認することができるものと考えられた。

\section{要 約}

本研究では, 雌アジアゾウの発情周期中における腔前庭 粘膜面の肉眼的変化と血中プロジェステロン濃度の変化と の関係を明らかにしようとした。血中プロジェステロン濃 度が最も低い時期の腟前庭粘膜面では明らかに広範囲の充 血が認められたが，血中プロジェステロン濃度の上昇に伴 い外陰部に近い充血部の周辺に紅斑や腫脹が散在し丘疹も 観察された。しかし，血中プロジェステロン濃度が減少す るにつれて粘膜面の充血が緩和する傾向があった。 キーワード：アジアゾウ, 腟前庭, プロジェステロン

\section{謝辞}

本稿作成に際し多大なご助言を賜った日本大学生物資源 科学部の村田浩一先生に深く感謝いたします。

\section{引用文献}

1. Hess DL, Schmidt AM, Schmidt MJ. 1983. Reproductive cycle of the Asian elephant (Elephas maximus) in captivity. Biol Reprod 28: 767-773.

2. Brannian JD, Griffin F, Papkoff H, Terranova PF. 1988. Short and long phases of progesterone secretion during the oestrous cycle of the African elephant (Loxodonta africana). $J R e$. prod Fertil 84: 357-365.

3. Taya K, Komura H, Kondoh M, Ogawa Y, Nakada K, Watanabe G, Sasamoto S, Tanabe K, Saito K, Tajima H, Narushima E. 1991. Concentrations of progesterone, testosterone and estradiol-17 $\beta$ in the serum during the estrous cycle of Asian elephant (Elephas maximus). Zoo Biology 10: 299-307.

4. Jainudeen MR, Katongole CB, Short RV. 1972. Plasma testos. terone levels in relation on musth and sexual activity in the male Asiantic elephant, Elephas maximus. J Reprod Fert 29: 99-103.

5. Doi O, Komatsumoto M, Terazono M, Wada S, Akihisa N, Sakamoto H. Hamasaki T. Yanagimoto H, Nakano K,

Matsuoka K. Ito A, Kusunoki H, Nakamura T. 2000. Exfoliative cytology in vaginal vestibule of female Asian elephants: Relation to circulating progesterone concentrations. Zoolog. Sci 17: 1303-1309.

6. 中村孝雄, 正殿誠秀, 田名部雄一. 1974. ラジオイムノアッセイによ る動物組織および体液中のエストラジオールおよびプロジエステロンの 微量定星法. 岥皁大農研報 36: 319-328.

7. Doi O, Kusunoki H, Sato T, Kawakami S, Fukuoka T, Okuda K, Ito O, Saito E, Hayashi T, Hase T, Kamiyoshi M. 2001. Serum progesterone and estradiol-17 $\beta$ concentrations, and lapaloscopic observations of the ovary in the cheetah (Acinonyx jubatus) with pregnant mare serum gonadotropin and human chorionic gonadotropin treatments. J.Vet.Med.Sci in press. 